\title{
Development Analysis of Badminton Specific Agility Test
}

\author{
Eval Edmizal $^{1 *}$, Vega Soniawan ${ }^{1}$ \\ ${ }^{1}$ Sport Coaching Education Program, Faculty of Sport Science, Universitas Negeri Padang \\ Indonesia \\ *Corresponding author. Email: eval.edmizal@yahoo.co.id
}

\begin{abstract}
The form of the test has no new discoveries or innovations, researchers designed or modified the specific test of badminton using the badminton court and its movements led to the game of badminton such as going forward, step right side, left side and backward. This study aims to determine the validity and reliability of badminton specific agility test. The sampling technique used was Purposive Sampling. It was determined to be a sample of 100 people. Retrieval of agility test data in badminton games, Shuttle Run Test, retesting of agility tests in badminton games were carried out by calculating the time. The Validity Test of Agility Tests in badminton games was sought by correlating the results of the agility test in badminton games with the results of the Shuttle Run Test, while the Reliability Test of agility tests in badminton games was sought by correlating the results of the agility test in badminton games with a retest of the agility test. badminton game. Based on the data analysis, the validity level of the specific Badminton Agility Test is 0.78, which means very good, while the Reliability level of the Agility Test in badminton games is 0.79 , which means acceptable.
\end{abstract}

\section{Keywords: Analysis Development, Badminton Specific Agility Test.}

\section{INTRODUCTION}

Based on observations and interviews conducted by the researchers as Lecturer Coaching courses basic badminton at FIK UNP, it was confirmed that in the lecture, there are still many basic badminton students who do not have the agility of movement of the foot in badminton bermaian. If this is allowed then the ultimate goal of achieving the maximum value and the increase in badminton playing skills will not be achieved. Therefore, this needs to be taken seriously for the achievement of objectives and to see upgrades footwork. The interview results show that only minimal faculty lecturer or trainer that uses a test to measure the level of ability footwork case. This is due the possibility of the absence of proper test to measure the level of ability of footwork player or the absence of a test that qualifies a good test in terms of validity and relability test.

\subsection{Test}

According [1], tests derived from the old French testum which means plate for designated types of valuable precious metals high. While in English called the test which means it is a test or a trial. According [2], "The test is a measure". Furthermore, [3] stated, "The test is a tool or procedures required to measure or know something by the way and certain rules ". Later, [4] argues, "The test is a tool or instrument used to obtain information or data about an individual or object". So, from the above third expert opinions, it can be argued that the test is a measurement tool to get information to achieve goals.
[5] argued that the test is one of the tools or procedures are required to collect the data a person, object or objects particular through measurement and certain rules. When taking a test called testing, while those who take tests called testee and the person entrusted to carry out test to respondents who will test called a tester.

So, it can be stated that the test is a measuring instrument to get information through measurements and certain rules in achieving goals so that it can produce appropriate and correct evaluation and follow-up. The test intended in this study is a test of sports skills.

\subsection{Validity}

According to [3] that validity comes from the word that means valid valid. A test is said to be valid if the test accurately measures what it is supposed to be tested. Furthermore, the degree of validity of a test called the validity. Later, [4] stated, "Validity is a measure of what should be measured, or the extent to which the instruments illustrate the accuracy in measuring what is supposed to be measured". So, a test is valid if the test is to measure what is supposed to be measured with great accuracy.

Meanwhile, according [6] states, "In order for a test to be valid, then the measurement should be reliable, but not necessarily a reliable measurement valid". That is, a test to measure what should be measured, must first be able to measure consistently.

Furthermore, [7] states, "The test can be said to be valid if the test mentioned measuring the object appropriately and in accordance with the symptoms measured. A test is said to be valid if the test accurately 
measures what it is supposed to be tested. Furthermore, the degree of validity of a test called the validity. Thus, a test of validity is if these tests measure what should be measured with great accuracy.

\subsection{Reliability}

According to [3], a test is said to be reliable if the test was to measure correctly what should be measured. Furthermore, [6] states that the reliability is the degree that shows (level) of a test.

[4] argues that term reliability likened by the term consisten stability or dependebility that that is to say could unbelievable reliable basically is show to what extent. The measurement can give different results relative or nearly the same when measurements were taken back the object of the same or different within the same or different.

Furthermore, [7] argues, "A measuring instrument has high reliability or can be trusted if the measuring instrument it steady." Thus, it is said to be stable measuring instrument means a measuring tool that is stable, reliable, and predictable.

The test is said to be reliable if the test was to measure precisely what should be measured. Therefore, to see the level of validity and reliability, a test needs to be tested its degree coefficient. Thus, researchers wanted to see the validity and reliability of the test agility in the game of badminton.

The objectivity of a test can be analyzed by correlating the value of the test results with the value of the same test results, but the data retrieval is done by other people on the same sample. Because the process will retrieve data again, the coefficient of objectivity is often not analyzed again if it has found a good coefficient of validity and reliability.

Based on expert opinion above, it can be argued that reliability is the degree that shows (level) a test. Reliability of the test in this study sought to test-retest method, the test values correlate with the value re-test (agility test in the game badminton) with use formula product moment.

\section{METHODS}

Descriptive Research is a study that attempted to describe and interpret the object in accordance with what it is. Thus, descriptive study takes issue or focus on actual problems descriptive study. Population in this study was all students who took the courses Coaching Badminton courses in Semester July-December 2018 as many as 182 people. The sampling technique used was purposive sampling namely the determination of the sample with the consideration of certain characteristics. It was determined to be samples study as many as 100 people.

The instrument that will be used in future research is the development of specific agility test in games or badminton.

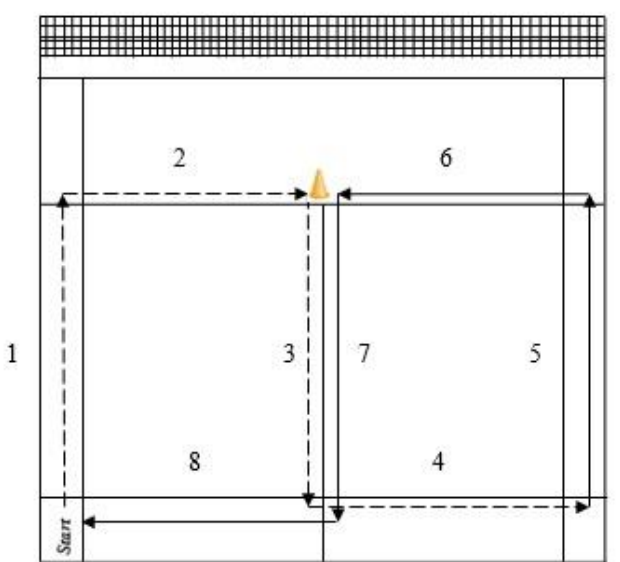

Figure 1. The Agility Test Field.

The steps of the test are, 1) the testee stands at the rear left side of the box to the field on a rectangular box or start area, 2) the testee moves when the whistle blows, then testee moving backward backward (number 3 ), hereinafter testee move laterally move right (number 4 ), then move forward testee (number 5), hereinafter testee move laterally move left (number 6), then work backwards moving testee (number 7), hereinafter testee move laterally move left (number 8 ) until towards the finish line is at the beginning of the box area / start. Scores were taken are the best time of 3 attempts needed to traverse the path that has been specified in seconds.

The instrument that will used as comparative data from the test instrument of Agility badminton is specific Shuttle Run Test (Agility Test) To analyze the validity and reliability using the formula product moment.

\section{RESULTS AND DISCUSSION}

\subsection{Data Description}

Based on the measurement results of the implementation of the test agility Specific Badminton Coaching Programs for students who take courses in the distribution of the data obtained badminton is mean 10.37, median 10.28, mode 10.12 , standard deviation 0.71 , the highest score 12.35 , the lowest score 9, variants 0.51 .

The measurement results of the implementation of the re-test Agility Badminton specific distribution of the data obtained on average 10.68 , median 10.63 , mode 10.31 , standard deviation 0.73 , the highest score 14.89 , the lowest score 10.11, variant 1.20.

Furthermore, the measurement results from Shuttle Run Test trials for Coaching Department students who took Badminton courses obtained an average data distribution of 12.22 , median 12.06 , mode 11.85 , standard deviation 1.09 , highest score 14.89 , lowest score 10.11, variant 1.20.

1.2 Data Analysis

Test Validity level agility Coaching Department students who take courses in Badminton in Semester 
July-December 2018, by correlating test scores Agility Badminton specific to Shuttle Run Test. The results of the analysis turned out to number of correlation showed $\mathrm{r}=0.78$, it can be said tests Agility Badminton specific coaching courses for students who take courses in Badminton is valid. So, level validity tests Agility Badminton specifically for students of Coaching included in the category very good.

Reliabelity level agility test Coaching Department students who take courses in Badminton in Semester July-December 2018, with correlate test scores Agility Badminton specific to test retest Agility Badminton specific. Result analysis turned out to show the number of correlation showed $r=0.79$, it can be said tests Agility Badminton specific coaching courses for students who take courses Badminton is Reliable. So the level of reliability Agility Badminton specific for college student Coaching Programs this included in the category acceptable.

\section{DISCUSSION}

Based on test data analysis agility college student department Coaching taking courses in Badminton Semester July-December 2018, the results of the analysis turned out to show the number of correlation showed $r=0.78$, it can be said tests Agility Badminton specific coaching courses for students who take courses Badminton is valid. So the level of validity test Agility Specific Badminton Coaching Programs for students is included in the very good category.

Based on data analysis after correlating the agility test scores in a game of badminton by correlating test scores Agility Badminton specific to retest test Agility Badminton specific. Result analysis turned out to show the number of correlation showed $r=0.79$, it can be said tests Agility Badminton specific coaching courses for students who take courses Badminton is Reliable.

\section{CONCLUSSION}

Based on the results of the research described in the previous sessions, it can be concluded that the level of validity of the specific Badminton Agility Test was 0.78 (Very Good). The level of reliability of specific Badminton Agility Tests was 0.79 (Acceptable).

\section{REFERENCES}

[1] Wiji Suwarno. Dasar-dasar Ilmu Pendidikan. Jokjakarta: Ar-Ruzz Media. 2009. pp 40-54

[2] Nurhasan. Tes dan Pengukuran Dalam pendidikan Jasmani. Prinsip-prinsip dan Penerapannya. Jakarta: Direktorat Dirjen Olahraga. 2001. pp 10-32

[3] Adnan, Aryadi. Tes dan Pengukuran Olahraga. Padang. 2005.pp 53-76
[4] Aziz, Ishak. Tes Pengukuran dan Evaluasi Pembelajaran Olahraga. Padang: FIK UNP. 2008.pp 25-54

[5] Arsil. Evaluasi Pendidikan Jasmani dan Olahraga. Padang: FIK UNP. 2010.pp 33-40

[6] Mulyono Biyakto Atmojo. Tes dan Pengukuran Dalam Pendidikan Jasmani/Olahraga. Surakarta: Lembaga Pengembangan Pendidikan (LPP) dan UPT Penerbitan dan Pencetakan UNS (UNS Press) Universitas Sebelas Maret Surakarta. 2007.pp 66-87

[7] Ismaryati. Tes dan Pengukuran Olahraga. Surakarta: Lembaga Pengembangan. 2008.pp $55-66$ 